\title{
Sepsis monitoring and therapy focus according to the individual needs of patients - case report
}

\section{Nadzor i liječenje sepse prema individualnim potrebama pacijenta - prikaz slučaja}

\author{
Mirjana Lončarić-Katušin*, Vlasta Kupres, Jasna Topić, Petar Mišković, Josip Žunić
}

General hospital Karlovac, Karlovac

"Corresponding author:

Dr. sc. Mirjana Lončarić-Katušin General Hospital Karlovac

Andrije Štampara 3, 47000 Karlovac

e-mail:mikatusi@inet.com

Abstract. Aim: Treatment and monitoring of the septic patient with individual approach applying Surviving sepsis campaign (SSC) recommendations, extracorporeal blood purification and cerebral oximetry monitoring. Case report: This is a case report of a female patient with clinical signs of septic shock and with multiple organ failure (renal, respiratory failure, hypotension, coagulation disorder, impairment of consciousness) in wich, in addition to standard treatment measures, extracorporeal blood purification (CytoSorb ${ }^{\circledR}$ CytoSorbents Corporation and CytoSorbents Medical Inc., United States) was applied. After the completion of the hospital treatment, the patient was discharged to home treatment. Conclusion: Control of hyperinflammatory response using extracorporeal blood purification and cerebral oximetry monitoring may be, in special cases - applying Surviving sepsis campaign (SSC) recommendations - option for individual approach in sepsis management and following multiorgan dysfunction management.

Key words: critical care; multiple organ failure; purification

Sažetak. Cilj: Liječenje i nadzor pacijentice sa sepsom prema individualnom pristupu u kojem je, uz preporuke SSC-a, primijenjena i ekstrakorporalna purifikacija krvi, a u nadzoru cerebralna oksimetrija. Prikaz slučaja: Ovo je prikaz slučaja pacijentice s kliničkim znakovima septičkog šoka i višestrukim zatajenjem organa (bubrezi, zatajenje disanja, poremećaj zgrušavanja, poremećaj svijesti), u kojem je, u dodatku standardnih mjera liječenja, primijenjena izvantjelesna purifikacija krvi (CytoSorb ${ }^{\circledR}$ - CytoSorbents Corporation and CytoSorbents Medical Inc., United States). Nakon završetka bolničkog liječenja pacijentica je otpuštena na kućno liječenje. Zaključak: Kontrola hiperinflamacijskog odgovora primjenom ekstrakorporalne purifikacije krvi i nadzor cerebralnom oksimetrijom mogu u pojedinim slučajevima biti - uz primjenu Međunarodnih smjernica o liječenju sepse - opcija individualnog pristupa nadzora i liječenja sepse i prateće multiorganske disfunkcije.

Ključne riječi: intenzivno liječenje; multiplo zatajenje organa; purifikacija

http://hrcak.srce.hr/medicina 


\section{INTRODUCTION}

In spite of the guidelines on the treatment, sepsis remains the leading cause of death in intensive medicine units ${ }^{1}$. The fundamental treatment recommendations can be found in the recommendations of the Surviving Sepsis Campaign $(\mathrm{SSC})^{2}$. Today, many of the other forms of supportive treatment of sepsis are applied as well. Mediators, released during sepsis, uncontrolledly damage a cell structure during the complex interactions $^{3}$. The control of a strong inflammatory response using the purification technique may thus be a therapeutic possibility for the sepsis treatment $^{3}$. The application of haemadsorption is a form of immunotherapy, which tries to control the development of sepsis.

Blood purification techniques indiscriminately remove inflammatory mediators ${ }^{4}$. In this context, extracorporeal blood purification is recognized as a potential immunotherapy of patients during sepsis, septic shock and multiple organ dysfunction syndrome (MODS) as well as with individual cases of patients with non-infectious conditions (postcardial operations, pancreatitis) resulting in high concentrations of cytokines and multiple organ disfunction. The heterogeneity of patients with sepsis and septic shock requires the individual diagnostic and therapeutic approach at the time of the control of vital functions including the selection of the treatment application which will best suit the patient.

\section{CASE REPORT}

This is a case report of a female patient with clinical signs of septic shock and MODS (renal, respiratory failure, hypotension, coagulation disorder, impairment of consciousness) in which, in addition to standard treatment measures, extracorporeal blood purification (CytoSorb ${ }^{\circledR}-$ CytoSorbents Corporation and CytoSorbents Medical Inc., United States) was applied.

A 30-year-old female patient with the stenosis of ureteropelvic junction of the left kidney was received at the urological department for high fever $\left(39^{\circ} \mathrm{C}\right)$, with pain in the left lumbar lodge and vomiting. At the reception, the patient was contactable (GCS 15), with global hemodynamics showing positive parameters of the inflam- mation (CRP: $291.8 \mathrm{mg} / \mathrm{L}, \mathrm{PCT}: 0.764 \mathrm{ug} / \mathrm{L})$. The native test of urine showed present urinary infection. Arterial blood gas (ABG) analysis: compensated metabolic acidosis. Renal ultrasound showed dilatation III/IV of the left kidney. Due to obstructive uropathy caused by concrement in the left renal pelvis, after skin disinfection and infiltration of local anesthetic in the left lumbar area, urologist performedpercutaneous nephrostomy under ultrasound control, $10 \mathrm{CH}$ catheter was set in place and fixed to the skin.

Control of hyperinflammatory response using extracorporeal blood purification and cerebral oximetry monitoring may be, in special cases - applying Surviving sepsis campaign (SSC) recommendations - option for individual approach in sepsis management and following multiorgan dysfunction management.

There was $200 \mathrm{ml}$ purulent urine on catheter after nephrostomy.

For blood culture, under sterile conditions, $5 \mathrm{ml}$ of blood sample was taken from central venous catheter and another $5 \mathrm{ml}$ of blood from a peripheral vein. At the same time, $5 \mathrm{ml}$ of urine sample was taken directly from Foley catheter with a sterile syringe for urine culture. After taking blood and urine samples, Ciprofloxacin was applied to intravenous therapy. Eight hours after the hospitalization, the patient developed a sepsis following MODS nad was transfered to the ICU. The patient was hypotensive, febrile $\left(40^{\circ} \mathrm{C}\right)$ with chills.

The resuscitation with crystalloid solutions was started. Leukopenia $\left(3.0 \times 10^{9} / \mathrm{L}\right)$ and thrombocytopenia ( $\operatorname{Tcr} 55 \times 10^{9} / \mathrm{L}$ ) were present together with an increase of procalcitonin (PCT $82.24 \mathrm{ug} / \mathrm{L}$ ). After administration of crystaloides in high doses, the patient was still hypotensive so vasopressors and non-invasive mechanical ventilation were aplied. In order to control global haemodynamics, the haemodynamic monitor LiDCO (LiDCO Ltd., England) was set, and the abdominal perfusion pressure $(\mathrm{APP})(\mathrm{APP}=$ Mean arterial pressure (MAP) - Intra abdominal pressure (IAP)) was monitored as well as the cerebral and hepatosplanchnic oxygenation (INVOS Covidien Ltd., Republic of Ireland). Escherichia coli sensitive to Ciprofloxacin was isolated from urine and blood culture. 
Table 1. The parameters before and after the application of "CytoSorb"

\begin{tabular}{|c|c|c|c|c|}
\hline Parametar & 18.05 .2015 & $\begin{array}{c}19.05 .2015 \\
\text { CYTOSORB } \\
\text { APPLICATION }\end{array}$ & 20.05.2015 & 21.05.2015 \\
\hline Mean arterial pressure $(\mathrm{mmHg})$ & 73 & 81 & 99 & \\
\hline $\mathrm{Cl}\left(\mathrm{l} / \mathrm{min} / \mathrm{m}^{2}\right)$ & 6.6 & 6.49 & 5.07 & \\
\hline SVRI (dynes $\cdot \mathrm{sec} / \mathrm{cm}^{5} / \mathrm{m}^{2}$ ) & 650 & 600 & 1550 & \\
\hline ITBVI & 1509 & 1505 & 1268 & \\
\hline $\mathrm{PaO}_{2} / \mathrm{FiO}_{2}$ & 5.8 & 12.2 & 16.7 & 15.9 \\
\hline Vazopressor & YES & YES & NO & NO \\
\hline pCO2 (kPa) & 7.18 & 8.47 & 6.25 & 6.79 \\
\hline $\mathrm{EE} / \mathrm{RQ}$ & & $1542 / 0.75$ & $987 / 0.75$ & \\
\hline INVOS S/C & $83 / 84$ & $76 / 63$ & $83 / 60$ & $82 / 52$ \\
\hline Respiration & NIMV & $\begin{array}{l}\text { NIMV/ } \\
\text { Bi-Level }\end{array}$ & Bi-Level & $\begin{array}{c}\text { Bi-Level/ } \\
\text { pa PSV- PEEP }\end{array}$ \\
\hline$L\left(\times 10^{9} / L\right)$ & 23.5 & 36 & 32.1 & 15.6 \\
\hline Creatinin (mmol/L) & 94 & 65 & 43 & 55 \\
\hline CRP (mg/L) & & 320.6 & 200.7 & 77.3 \\
\hline PCT (ng/ml) & & 17.34 & 6.64 & 4.13 \\
\hline Thrombocytes $\left(\times 10^{3}\right)$ & 60 & 58 & 37 & 57 \\
\hline Lactates (mmol/L) & 2.91 & & 1.45 & 1.58 \\
\hline
\end{tabular}

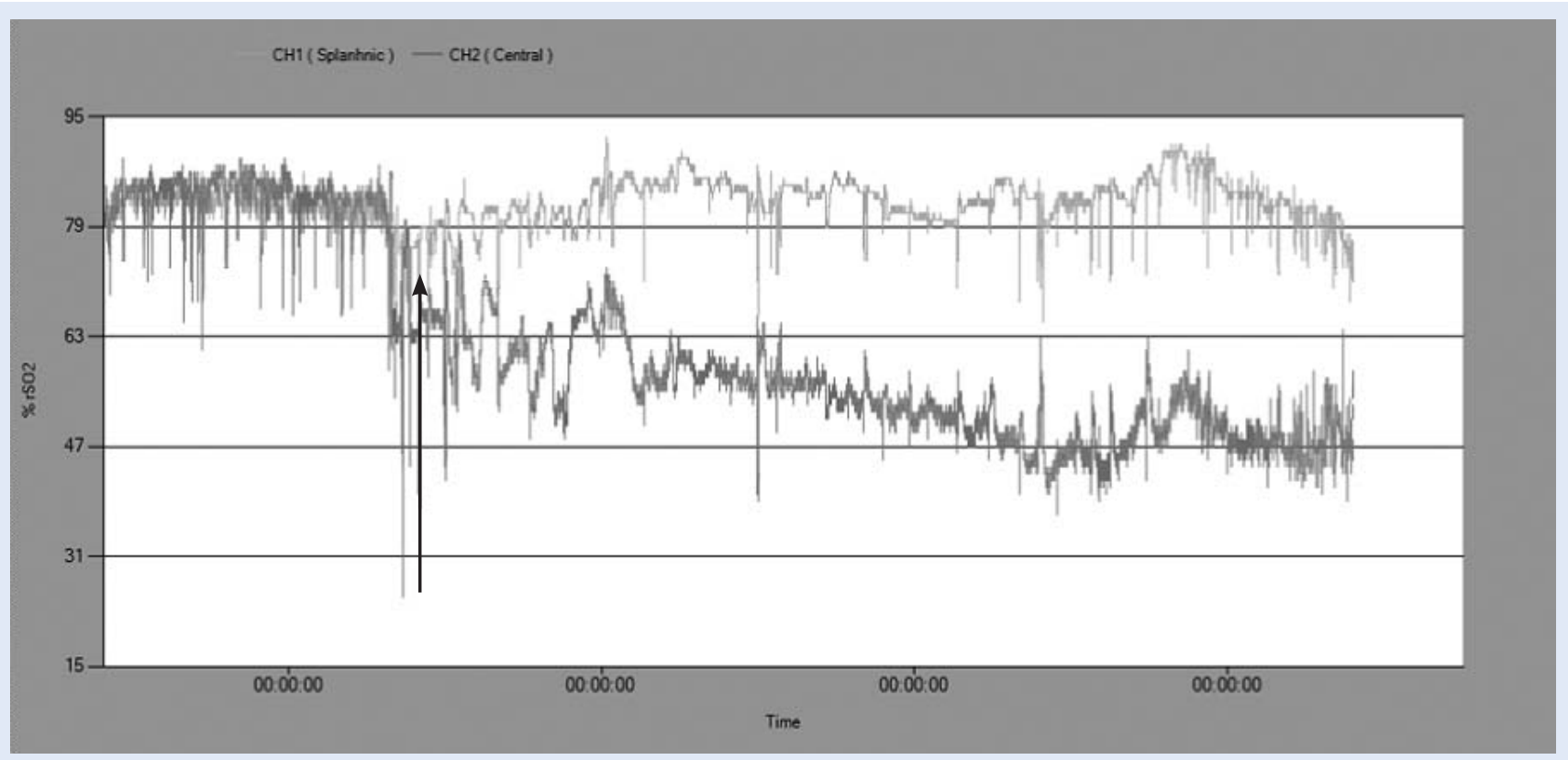

Figure 1. Tissue Oxygenation of the brain and liver. The figure of tissue oxygenation of the brain and liver. The arrow indicates the moment of a sharp decline due to saturation of the brain which indicated the emergency MRI.

On the third day of a hospital stay, the respiratory insufficiency further deteriorated $\left(\mathrm{PaO}_{2} 7.7 \mathrm{kPa}\right.$, $\mathrm{pCO}_{2} 30.6 \mathrm{kPa}$ ), together with the impairment of consciousness and renal insufficiency (creatinine $170 \mathrm{mg} / \mathrm{L}$ ). An increase in laboratory parameters of inflammation (PCT > 100 ug/L, CRP 40251.2 $\mathrm{mg} / \mathrm{L})$ was noted as well. Radiological lung find- ings show diffuse consolidation zones of lung parenchyma. Transthoracic echocardiography shows Pulmonary arterial hypertension (PAH) 40-45 $\mathrm{mmHg}$, and ejection fracion (EF) of $25 \%$.

On the fourth day of her hospital stay, there was a further progression of respiratory failure (hypoxemia, hypercapnia, reduction of respiratory index) 
due to which an invasive mechanical ventilation (Bi Level one) was applied. The metabolism was controlled by the method of indirect calorimetry (General Electric, USA). The global hemodynamics was maintained by applying norepinephrine and dobutamine. On the same day, the adjuvant therapy - extracorporeal blood purification (CytoSorb) with the application of continuous veno - venous hemofiltration for 15 hours was introduced in the treatment. After the introduction of the therapy the stabilization of global haemodynamics (recovery of Cardiac indeks $(\mathrm{Cl})$, Systemic vascular resistance indeks (SVRI), Intra toracic blood volume indeks (ITBVI), the abolition of norepinephrine and dobutamine) was observed.

The recovery of laboratory markers of hypoperfusion (lactate, bicarbonate, $\mathrm{ScvO}_{2}$ ) and laboratory parameters of inflammation (L, CRP, PCT) followed. Patient's energy needs decreased as well, while an increase in respiratory index was noticed and the mechanical respiratory support was reduced. The respiratory support was revoked on the second day after the end of therapy with Cytosorb (Table 1). The hepatic-splanchnic perfusion was maintained, but the brain oxygenation was not noticed (INVOS) (Figure 1). Magnetic resonance imaging of the brain showed multiple cerebral abscesses. On the thirteenth day of patient's hospital stay, she was moved to the ward, and after twenty days in hospital she was released to home treatment.

\section{DISCUSSION}

We present a case of 30-year-old female patient with a clinical picture of a septic shock and sepsis. The patient was treated according to standard recommendations for the treatment of sepsis $^{2}$. Despite the therapeutic measures undertaken, on the fourth day of her stay there was a progression of multiple organ failure with the need for the application of invasive mechanical ventilation, increased dose of vasopressors and the introduction of inotropes. The application of Cytosorb was indicated as an adjuvant form of the sepsis treatment aimed at the nonselective removal of inflammatory mediators, the control of a strong inflammatory response and sepsis ${ }^{3}$. The success of the application of CytoSorb in patients with sepsis is described in the literature ${ }^{6,7}$. In the patient, a rapid haemodynamic stabilization was observed, with the reduction of vasopressors and inotropes dosage, within a few hours from the onset of the application of CytoSorb, as well as the reduction of inflammation markers. Unfortunately, the analysis of proinflammatory cytokines due to technical reasons could not have been analysed. The safety of the method and good tolerance by the patient was confirmed. The clinical stabilization of the patient, in addition to improved haemodynamic stability, can be seen in the improvement of respiratory function measured by $\mathrm{PaO}_{2} / \mathrm{FiO}_{2}$ ratio $^{8}$ as well. The improvement in respiratory function was also observed in the patient, with a consequent abolition of mechanical respiratory support and the restoration of a sufficient spontaneous ventilation.

The objective control of a series of pathophysiological and physiological disorders is necessary for a timely intervention. Therefore, the assessment of sufficient supply of oxygen in patients with sepsis is the key of a prevention, early identification and timely intervention in organic failure $^{9}$. By controlling the cerebral oxygenation (INVOS), the decrease in brain oxygen saturation was observed in the patient which is why the MRI of the brain was indicated, which further showed the development of multiple abscesses in the brain. Using the method of indirect calorimetry, the metabolic changes were followed, which enabled the implementation of correct nutritional support.

\section{CONCLUSION}

In critically ill patients, the control of not only of the global and regional haemodynamics, respiratory function and the parameters of inflammation, but also the functions of a number of other organs, systems and metabolism is necessary. Comprehensive monitoring forms the basis for the application of therapeutic procedures and personalized therapies. This case indicates that the therapy with Cytosorb may be an option in the treatment of patients with septic shock and developed multiple organ failure due to the possible control of the hyperinflammatory response.

Conflicts of interest statement: The authors report no conflicts of interest. 


\section{REFERENCES}

1. Angus DC, van der Poll T. Severe sepsis and septic shock. N Engl J Med 2013;369:840-51.

2. Dellinger RP, Levy MM, Rhodes A, Annane D, Gerlach H, Opal SM et al. Surviving Sepsis Campaign Guidelines Committee Including the Pediatric Subgroup. Surviving Sepsis Campaign: international guidelines for management of severe sepsis and septic shock: 2012. Crit Care Med 2013;41:580-637.

3. Rimmelé T, Kellum JA. Clinical review: blood purification for sepsis. Crit Care 2011;15:205.

4. Vincent JL, Rhodes A, Perel A, Martin GS, Della Rocca G, Vallet $B$ et al. Clinical review: Update on hemodynamic monitoring - a consensus of 16. Crit Care 2011;15:229.

5. Ekbal NJ, Dyson A, Black C, Singer M. Monitoring Tissue Perfusion, Oxygenation, and Metabolism in Critically III Patients. Chest 2013;143:1799-808.
6. Hinz B, Jauch O, Noky T, Friesecke S, Abel P, Kaiser R. CytoSorb, a novel therapeutic approach for patients with septic shock: a case report. Int J Artif Org 2015;38:461-4.

7. Basu R, Pathak S, Goyal J, Chaudhry R, Goel RB, Barwal A. Use of a novel hemoadsorption device for cytokine removal as adjuvant therapy in a patient with septic shock with multi-organ dysfunction: A case study. Indian J Crit Care Med 2014;18:822-4.

8. Träger K, Schütz C, Fischer G, Schröder J, Skrabal C, Liebold A et al. Cytokine Reduction in the Setting of an ARDS-Associated Inflammatory Response with Multiple Organ Failure. Case Rep Crit Care 2016;2016:9852073.

9. Nasirul J, Ekbal MBBS, Dyson A, Black C, Singer M. Monitoring Tissue Perfusion, Oxygenation, and Metabolism in Critically III Patients. Chest 2013;143:1799-808.

10. Moreira da Rocha EE, Alves VGF, da Fonseca RBV. Indirect calorimetry: methodology, instruments and clinical application. Curr Opin Clin Nutr Metab Care 2006;9:247-56. 